Research

\title{
Salbutamol Residue in Plasma and Urine of Balinese Calves after Single-Dose Administration
}

\author{
Yessy Anastasia', Hadri Latif ${ }^{*}$, Lina Noviyanti Sutardi², Raphaella Widiastuti ${ }^{3}$ \\ 1Department of Veterinary Public Health, Faculty of Veterinary Science, IPB University \\ Jalan Agatis, Kampus IPB Dramaga Bogor 16680, Indonesia \\ ${ }^{2}$ Department of Veterinary Clinic Reproduction and Pathology, Faculty of Veterinary Medicine, IPB University \\ Jalan Agatis, Kampus IPB Dramaga Bogor 16680, Indonesia \\ ${ }^{3}$ Department of Toxicology, Indonesian Research Center for Veterinary Science \\ Jalan RE Martadinata No 30 Bogor 11614, Indonesia \\ ${ }^{*}$ Corresponding author: hadrilatif@gmail.com \\ Submitted 15 July 2020, Accepted 13 December 2020
}

\begin{abstract}
Salbutamol, a short-acting $\theta_{2}$-adrenergic receptor agonist, due to illegal use in animal feed, is very dangerous for the safety of animal origin products. The purpose of this study is to determine the residue of salbutamol in plasma and urine of balinese calf after a single-dose administration. Three calves were given of feed fortification of salbutamol (10 mg/kg body weight). The salbutamol concentrations were measured in the plasma and urine. Samples were extracted with perchloric acid and purified by cation exchange solid phase extraction (SPE), then analyzed by High-Performance Liquid Chromatography (HPLC) with a photodiode array detector using an RP C18 column with a mixed mobile phase of purified water $\mathrm{pH} 3.0$ (adjusted with phosphoric acid) and acetonitrile (90:10, v/v). The highest salbutamol concentration in the plasma sample was $0.28 \pm 0.15 \mu \mathrm{g} / \mathrm{mL}$ at 12 hours and decreased after 24 hours after feeding. The highest concentration of salbutamol in urine was $15.85 \pm 4.42 \mu \mathrm{g} / \mathrm{mL}$ at 18 hours and decreased gradually starting at 24 hours. This result concluded that salbutamol residues mostly excreted in the urine, and the highest salbutamol residues in plasma samples formed faster but also decreased more rapidly than residues formed in urine. The residue formed in plasma is lower than that in the urine.
\end{abstract}

Keywords: HPLC, plasma, salbutamol, balinese calf, urine

\begin{abstract}
ABSTRAK
Salbutamol, adrenoseptor $\boldsymbol{B}_{2}$-selektif kerja pendek, karena penggunaan illegal dalam pakan ternak, sangat berbahaya bagi keamanan produk asal hewan. Penelitian ini bertujuan untuk mengukur kadar residu salbutamol yang terbentuk dalam plasma dan urin pedet sapi bali setelah pemberian salbutamol dosis tunggal. Tiga ekor pedet diberi pakan mengandung salbutamol (10 mg/kg bobot badan). Konsentrasi salbutamol diukur dari sampel plasma dan urin. Sampel diekstraksi dengan asam perklorat dan dipurifikasi dengan solid phase extraction (SPE) cation exchange, kemudian dianalisis secara kromatografi cair kinerja tinggi (KCKT) dengan detektor photodiode array menggunakan kolom RP C18 dengan fase gerak campuran purified water pH 3.0 (disesuaikan dengan asam fosfat) dan asetonitril (90:10, v/v). Konsentrasi salbutamol tertinggi sampel plasma sebesar $0.28 \pm 0.15 \mu \mathrm{g} / \mathrm{mL}$ pada jam ke-12 dan menurun pada jam ke-24. Konsentrasi tertinggi urin sebesar $15.85 \pm 4.42 \mu \mathrm{g} / \mathrm{mL}$ pada jam ke-18, dan menurun secara bertahap mulai jam ke-24. Disimpulkan bahwa residu salbutamol sebagian besar dieksresikan di urin dan residu tertinggi salbutamol pada sampel plasma lebih cepat terbentuk namun juga lebih cepat menurun dibandingkan residu yang terbentuk pada urin. Residu yang terbentuk pada plasma lebih rendah dibandingkan yang terbentuk pada urin.
\end{abstract}

Kata kunci: KCKT, plasma, salbutamol, sapi bali, urin 


\section{INTRODUCTION}

Beta-agonist have been illegally used to improve carcass conditions and performance of livestock production. Meat products from animals treated by B-agonist with long plasma half-lives, high oral bioavailability, may have high oral potencies of 8 agonist in humans. On the other hand, 8 -agonist with short plasma half-lives, low oral bioavailability, have low oral potencies in consumers as the shorter plasma half-life leads to much lower residues in edible tissue and a much lower risk to consumers (Smith, 1998). The residue of $B_{2}$-agonists in the tissues, organs, and processed products accumulating in the human body can have adverse effects on human health (Du et al., 2013; Zhang et al., 2017). Numerous literature has reported various potential hazards and adverse effects of $B_{2}$-agonists, including cardiovascular effects, and affect the central nervous system (Hung et al., 2010). However, now a day public concern is more focused on clenbuterol than salbutamol, so there is a possibility that salbutamol illegally used as a substitute for clenbuterol (Granja et al., 2017; Tang et al., 2018).

Salbutamol, a short-acting $\beta_{2}$-adrenergic receptor agonist, is widely used to treat respiratory diseases acting as tocolytic and bronchodilator agents in animals and humans (Yan et al., 2016). The administration of salbutamol in high doses ( $\geq 10$ fold than the therapeutic dose) can cause repartition effects, feed efficiency, increase body weight gain, and lean carcasses, by converting nutrients from fat deposition to production muscle tissue (Lei et al., 2008; Marchant-Forde et al., 2012; Hung et al., 2010).

Various methods for detecting residue of $\beta_{2}$ agonists have developed, namely immunoassay (Pleadin et al., 2013), chemiluminescent (Gao et al., 2014), molecularly imprinted polymer (Tang et al., 2018) and high-performance liquid chromatography (HPLC) with ultraviolet detectors (Du et al., 2013; Yan et al., 2016), or fluorescence detectors (FLD) (Hu et al., 2010). Among these methods, HPLC is one of the most widely used methods.

Several studies have reported the elimination (depletion) of salbutamol in plasma and urine in the calf (Hung et al., 2010), adult dairy cows (Zhang et al., 2016), and Chinese Simmental beef cattle (Zhang et al., 2017). However, the use of Balinese (Bos javanicus) cattle (domestic subspecies originated in Indonesia) (Mohamad et al., 2009) for study, its elimination has never been reported. This research is a preliminary study, conducted to detect levels of salbutamol in plasma and urine of balinese calves after a single dose of feed fortification, using HPLC with a photodiode array detector.

\section{MATERIALS AND METHODS}

\section{Animal ethic approval}

All procedures in this study have approved by the Institutional Animal Care and use Committee (IACUC) of Indonesian Agency for Agriculture Research and Development, Ministry of Agriculture No. Balitbangtan/BBLitvet/RM/02/2019.

\section{Chemicals}

Salbutamol standard (99.5\%) was purchased from Sigma Aldrich (USA). All other chemicals were commercially available from Merck (Darmstadt, Germany), except ultrapure water was provided from Millipore (MA, USA) and acetonitrile grade purchased from Tedia (USA). Solid-phase extraction (SPE) cation exchange PCX Plexa columns (60 mg, 3 $\mathrm{mL}$ ) (Agilent, USA).

\section{Animal and Sampling Procedures}

The experiment was conducted three healthy male Balinese (Bos javanicus), with 110, 128, and 100 $\mathrm{kg}$ in weight at the beginning of the treatment were used for this study. All calves were fed concentrate fortified by a single dose of $10 \mathrm{mg}$ of salbutamol $/ \mathrm{kg}$ $\mathrm{BW}$ in the morning feeding.

Blood samples were collected at 2, 6, 8, 12, and 24 hours after administration, and urine samples at $6,12,24,48,72,96,120$ and, 144 hours, after the drug was administered. Blood samples were taken from the jugular vein into a blood tube containing heparin anticoagulant, then centrifuged at 3000 rpm for 10 minutes to separate the plasma. Plasma and urine samples are stored at $-20^{\circ} \mathrm{C}$ before analyzed.

\section{Preparation of plasma and urine samples}

Analysis of plasma and urine samples referred to the method developed by Zhang et al. (2017) with modification. A $1 \mathrm{~mL}$ aliquot of plasma or urine samples were placed in a $15-\mathrm{mL}$ centrifuge tube, 4 $\mathrm{mL} 0.5 \%$ perchloric acid in water was added, and the sample was mixed on a vortex mixer for $1 \mathrm{~min}$. After centrifugation for $10 \mathrm{~min}$ at $4000 \mathrm{rpm}$, the supernatant was loaded onto a solid phase extraction PCX column that had been activated with $3 \mathrm{~mL}$ of methanol and $3 \mathrm{~mL}$ of water, washed with 3 
$\mathrm{mL}$ of $2 \%$ formic acid and $3 \mathrm{~mL}$ of methanol: acetonitrile $(50: 50, \mathrm{v} / \mathrm{v})$, and finally eluted with $5 \mathrm{~mL}$ of $5 \%$ ammonium in methanol: acetonitrile (50:50, $\mathrm{v} / \mathrm{v})$. The eluent was evaporated to dryness, under nitrogen gas at $40^{\circ} \mathrm{C}$, then reconstituted in $1 \mathrm{~mL}$ for plasma samples, and $1 \mathrm{~mL}$ for urine samples of a mixture of purified water $\mathrm{pH} 3.0$ (adjusted with orthophosphoric acid) and acetonitrile $(9: 1, \mathrm{v} / \mathrm{v})$, ready to be injected onto the HPLC.

\section{Equipment and Chromatographic Condition}

Analysis of salbutamol residues in plasma and urine samples was carried out using the HPLC Shimadzu LC-20AD, which was equipped with a Labsolution data analysis system, as well as a photodiode array detector at $225 \mathrm{~nm}$ (Shimadzu, Japan). The analytical separation process was carried out using an XTerra C18 column ( $150 \mathrm{~mm} \times 4.6 \mathrm{~mm}$, i.d $5 \mu \mathrm{m}$ ) (Waters, USA). The mobile phase used was a mixture of purified water $\mathrm{pH} 3.0$ (adjusted with orthophosphoric acid) and acetonitrile (9:1, v/v with a flow rate of $0.7 \mathrm{~mL} / \mathrm{min}$. The sample injection volume was $20 \mu$ l.

\section{RESULTS}

Different mobile phase mixtures with different $\mathrm{pH}$ have been experimented to obtain separation peak with excellent resolution and reasonable retention times. During the optimization process, blank and positive samples were injected to get a good separation between the matrix sample peak and the salbutamol peak. A mixture of purified water with $\mathrm{pH} 3.0$ (adjusted using phosphoric acid) and acetonitrile $(90: 10, v / v)$ was used to obtain the optimal separation of salbutamol peak with good retention time. The analysis time was relatively short, and salbutamol detected at a minute of 3.9. Figure 1 shows the chromatogram of salbutamol standard. The limit detection (LOD) and limit quantitation (LOQ) were evaluated as the amount required to achieved signal to noise ratio of 3:1 and 10:1, respectively. LOD and LOQ were 0.008 and $0.012 \mu \mathrm{g} / \mathrm{mL}$ for plasma samples and 0.026 and $0.036 \mu \mathrm{g} / \mathrm{mL}$ for urine samples, respectively.

Figures 2, shows the increase of the salbutamol concentrations residue in plasma at 12 hours, and decreasing at 24 hours after administration. Salbutamol

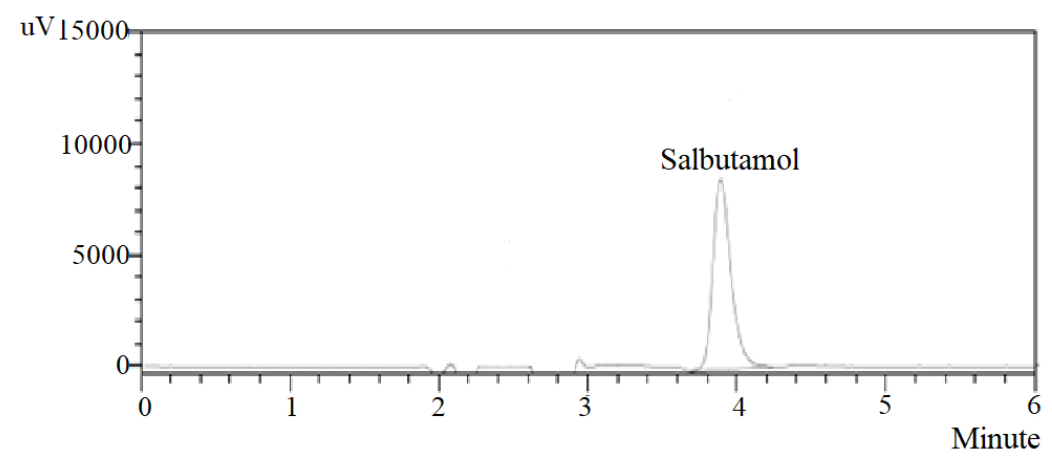

Figure 1 Chromatograms of salbutamol standard $1.0 \mu \mathrm{g} / \mathrm{mL}$

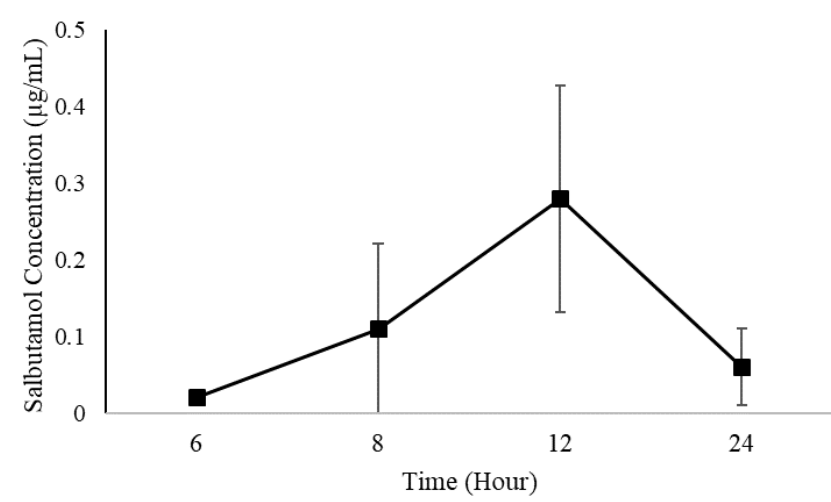

Figure 2 Salbutamol residues in plasma samples collected after single-dose drug administration 
concentrations in plasma at 2 hours after administration were below the limit quantification, then at $6,8,12$, and 24 hours after administration, the average of salbutamol concentration in plasma were $0.02,0.11,0.28$ and $0.06 \mu \mathrm{g} / \mathrm{mL}$.

The increase of salbutamol concentration also occurs in the urine sample shown in Figures 3. The highest concentration occurred 18 hours after administration, then decreased in $24,48,72,96,120$, and 144 hours with consecutive concentrations. The peak concentration of salbutamol in urine samples occurred 18 hours after administration of 15.85 $\mu \mathrm{g} / \mathrm{mL}$, then decreased in $24,48,72,96,120$ and 144 hours with consecutive concentrations of 5.12, 2.8, $0.4,0.23,0.07$ and $0.014 \mu \mathrm{g} / \mathrm{mL}$.

\section{DISCUSSION}

Our findings show the same patterns compared to the study conducted on heifers (Zhang et al., 2016), who showed that the highest in unhydrolyzed plasma occurred at $12 \mathrm{~h}$ and decreased subsequently. Distribution of salbutamol in pigs shows a high drug concentration in serum 5 hours after the last administration of salbutamol, and the half-life of salbutamol absorption after oral administration is about 4.01 $\pm 0.2 \mathrm{~h}$ (Suppadit, 2005). The study of Pou et al. (1992) reported salbutamol concentration in plasma veal calves did not detect on day 4 , after the last administration of milk fortification (10 $\mathrm{mg} /$ day) for ten days.
The study from Zhang et al. (2016) in heifers, shows that the highest salbutamol concentration from urine samples was at 8 hours and did not show the data at 12 and 18 hours after administration. The steady condition that occurred from these studies was similar and started at $72 \mathrm{~h}$. Pou et al. (1992) reported that immunoreactive salbutamol was detected in the urine sample taken in the evening after morning administration. In this study, the salbutamol concentration occurred at the urine samples at 18 hours and show signal suppression. This increase could be related to the presence of metabolites. However, salbutamol metabolites could not be measured since no hydrolysis procedure performed.

According to our study, the salbutamol had a long detectable period for six days (Figure 3). The study on unhydrolyzed samples of dairy heifers urine, salbutamol detected below the limit of quantitation $(0.2 \mathrm{ng} / \mathrm{mL})$ on $48 \mathrm{~h}$ and $120 \mathrm{~h}$, respectively, after single-dose oral administration through phosphate-buffered saline (Zhang et al., 2016). Similar to this study, salbutamol begins to reach eliminate phase after $48 \mathrm{~h}$, and decreases until $144 \mathrm{~h}$ after administration. Research conducted by Montrade et al. (1995) showed that salbutamol concentration decreased rapidly in urine and also from body tissues, after half-life, except kidney and liver.

The salbutamol variation of concentrations in plasma and urine samples from three individual cattle may be due to the consumption of feed from each Balinese calves (Figures 3), which did not accustom to consume concentrate but grass instead.

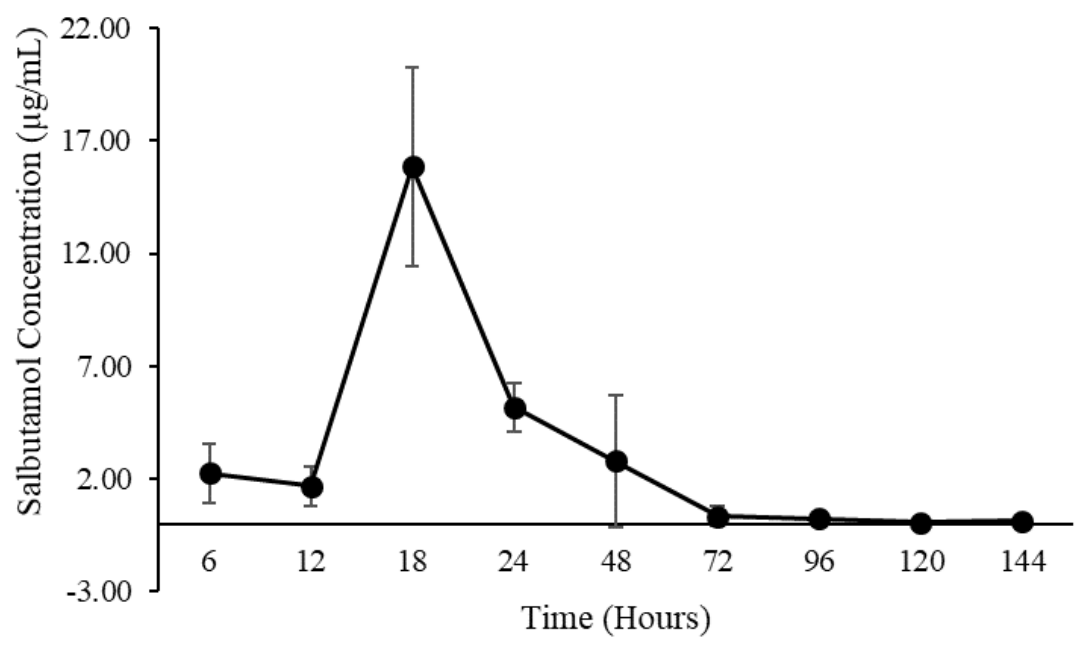

Figure 3 Salbutamol residue in urine samples collected after single-dose drug administration 
Beyene (2015) suggested that diet can affect the bioavailability of a drug. Further explained that animals receiving feed containing fresh green herbage had lowered bioavailability of the drug, also the drug uptake and pharmacodynamics also affected by gut contents. Decheng et al. (2015) observed that the variability in rates also might be related to the different times of sample collection, which implemented to the difficulties in collecting, especially the plasma samples.

Plasma and urine samples in food-producing animals, generally considered to be used as monitoring samples of the illegal use of $\beta 2$-agonists. The findings show that the plasma concentrations of salbutamol during the treatment period are lower compared with urine samples and rapidly decreases after administration. Therefore, our findings indicate that for preslaughter monitoring, urine is more suitable as a target of the illegal use of salbutamol.

The salbutamol residue in plasma samples is formed rapidly but also decreased faster than the residue formed in urine. The residue concentration in plasma is lower than urine.

"All authors declare that there are no conflicts of interest".

\section{REFERENCES}

Beyene T. 2015. Veterinary drug residues in foodanimal products: its risk factors and potential effects on public health. Journal of Veterinary Science Technology 7(1): 1-7.

Decheng S, Yu ZWZ, Genlong G, Ruigou W, PeiLong W, Xiaoou S. 2015. Validation of a confirmatory method of salbutamol in sheep hair by UPLCMS/MS and its application to a pharmacokinetic study. Journal of Pharmaceutical and Biomedical Analysis 114: 12-15.

Du W, Zhang S, Fu Q, Zhao G, Chang C. 2013. Combined solid-phase microextraction and high-performance liquid chromatography with ultraviolet detection for the simultaneous analysis of clenbuterol, salbutamol, and ractopamine in pig samples. Biomedical Chromatography 27(12): 1775-1781.

Gao H, Han J, Yang S, Wang Z, Wang L, Fu Z. 2014. Highly sensitive multianalyte immunochromato- graphic test strip for rapid chemiluminescent detection of ractopamine and salbutamol. Analytica Chimica Acta 839: 91-96.

Granja RHMM, Reche KVG, Giannotti FM, de Souza JKG, Ferrari SPG, dos Santos AD, Wanschel ACBA, Salerno AG. 2017. Laboratory validation of an LCMS/MS method for the detection of ractopamine, clenbuterol, and salbutamol in bovine and swine muscle at sub- $\mu \mathrm{g} \mathrm{kg-1}$ regulatory limits. Food Additives \& Contaminants: Part A 34(5): 785-792.

Hu YL, Liu RJ, Li YW, Li GK. 2010. Investigation of ractopamine imprinted polymer for dispersive solid-phase extraction of trace $\beta$-agonists in pig tissues. Journal of Separation Science 33(13): 2017-2025.

Hung $\mathrm{MJ}$, Huang $\mathrm{HH}$, Chen $\mathrm{CL}, \mathrm{Wu} \mathrm{YJ}$, Dixon KM, Mao CL. 2010. Salbutamol residues in swine tissues and body fluids after feeding. Thai Journal of Veterinary Medicine 40(4): 399-404.

Lei YC, Tsai YF, Tai YT, Lin CY, Hsieh KH, Chang TH, Sheu SY, Kuo TF. 2008. Development and fast screening of salbutamol residues in swine serum by an enzyme-linked immunosorbent assay in Taiwan. Journal of Agricultural and Food Chemistry 56(14): 5494-5499.

Mohamad K, Olsson M, van Tol HTA, Mikko S, Vlamings $\mathrm{BH}$, Andersson $\mathrm{G}$, Rodríguez-Martínez $\mathrm{H}$, Purwantara B, Paling RW, Colenbrander B. 2009. On the origin of Indonesian cattle. PLoS One 4(5): 1-6.

Marchant-Forde JN, Lay DC, Marchant-Forde RM, McMunn KA, Richert BT. 2012. The effects of RSalbutamol on growth, carcass measures, and health of finishing pigs. Journal of Animal Science 90(11): 4081-4089.

Montrade MP, Le Bizec B, Monteau F, Andre F. 1995. Analysis of $\beta$-agonists in urine and tissues by capillary gas chromatography-mass spectrometry: In vivo study of salbutamol disposition in calves. Food Additives and Contaminants-Part A 12(5): 525-636.

Pleadin J, Vulić A, Perši N, Terzić S, Andrišić M, Žarković I, Šandor K, Perak E. 2013. Comparison of ractopamine residue depletion from internal tissues. Immunopharmacology Immunotoxicology 35(1): 88-92.

Pou K, Adam A, Lamothe P, Gravel P, Messier J, Gravel A, Ong H. 1992. Serum and urinary levels of 
salbutamol after chronic oral Administration in a calf. Canadian Veterinary Journal 33(7): 467-468.

Smith DJ. 1998. The pharmacokinetics, metabolism, and tissue residues of $\beta$-adrenergic agonists in livestock. Journal of Animal Science 76(1): 173-194.

Suppadit T. 2005. The effect of beta-agonist (salbutamol) residue in pork on consumer health. Journal of Environmental Management 1(1): 1-8.

Tang J, Wang J, Shi S, Hu S, Yuan L. 2018. Determination of $\beta$-agonist residues in animalderived food by a liquid chromatographytandem mass spectrometric method combined with molecularly imprinted stir bar sorptive extraction. Journal of Analytical Methods and Chemistry 2018: 1-10.
Yan K, Zhang H, Hui W, Zhu H, Li X, Zhong F, Tong X, Chen C. 2016. Rapid screening of toxic salbutamol, ractopamine, and clenbuterol in pork sample by high-performance liquid chromatographyUV method. Journal of Food and Drug Analysis 24(2): 277-283.

Zhang K, Liang X, Su C, Tang C, Zhao Q, Zhang J, Meng Q. 2016. Salbutamol residues in plasma, urine, and hair of heifers after single-dose and throughout. Journal of Analytical Toxicology 40(6): 454-459.

Zhang K, Tang C, Meng Q, Du W, Bo T, Zhao Q, Liang X, Liu S, Zhang Z, Zhang J. 2017. Residues of salbutamol and identification of its metabolites in beef cattle. Journal of Agricultural and Food Chemistry 65(13): 2867-2875. 